\title{
ANALISA PERBAIKAN KINERJA PENGIRIMAN PRODUK R754046 DI PT PELANGI ELASINDO DENGAN PENDEKATAN SAFETY STOCK
}

\author{
JOKO HARDONO ${ }^{1}$, DIAN F.HIDAYAT ${ }^{2}, \&$ DEWI IRAWATI ${ }^{3}$ \\ ${ }^{1,2)}$ Staff Pengajar Program Studi Teknik Industri, Fakultas Teknik \\ ${ }^{3)}$ Mahasiswa Program Studi Teknik Industri, Fakultas Teknik \\ Universitas Muhammadiyah Tangerang \\ Jl. Perintis Kemerdekaan I/33, Cikokol, Kota Tangerang \\ Email:jhardono@yahoo.com ${ }^{1}$,henri_ponda@umt.ac.id ${ }^{2}$
}

\begin{abstract}
PT Pelangi Elasindo is one of the leading manufacturers in Indonesia specializing in webbing production, shoelaces, cords, high quality Molded Pulp, elastics and tape. As one of the vendors for leading shoe factories in the world, the accuracy of shipping goods both in terms of quantity and time is very important because this is a benchmark for calculating shipping performance. There was a delay in delivery at PT Pelangi Elasindo on the R7540460000 Molded Cardboard Shape size 2 product, making delivery performance decrease. Delivery performance in January is $93 \%$ while the minimum delivery performance standard is $95 \%$. This study aims to analyze the factors that delay the delivery of goods to customers and improve delivery performance. Based on the results of the analysis, the factors that cause the delay in delivery are damage to the machine, manual cutting and demand variations and uncertainty of lead time. Among these factors, demand variations and lead time uncertainty are the most influential factors, so to improve delivery performance, safety stock must be prepared to avoid stock outs and delivery delays. Based on the results of the calculation of the safety stock that must be prepared is 8,403 prs per week.
\end{abstract}

Key Words: Delivery, Performance, Safety Stock, Improve.

\section{PENDAHULUAN}

Semakin meningkatnya persaingan, pela$\mathrm{ku}$ industri mulai sadar bahwa untuk menyediakan produk murah, berkualitas, cepat, dan perbaikan di internal perusahaan tidaklah cukup. Ketiga aspek tersebut membutuhkan peran serta semua pihak mulai dari pemasok hingga ke konsumen. Hal ini membuat delivery performance dan kepuasan pelanggan menjadi penting dalam penguatan daya saing perusahaan.

PT Pelangi Elasindo merupakan salah satu produsen terkemuka di Indonesia yang mengkhuskan diri dalam produksi webbing, tali sepatu, cords, Moulded Pulp, elastics and tape yang berkualitas tinggi. Perkembangan zaman dan teknologi membuat persaingan bisnis di bidang aksesoris sepatu terus meningkat, hal itu membuat PT Pelangi Elasindo terus melakukan perbaikan agar dapat bertahan di tengah persaingan global. Untuk memenuhi harapan dan memberikan kepuasan kepada pelanggan, PT Pelangi Elasindo mengacu pada layanan yang baik, kualitas yang lebih baik dan harga yang kompetitif. Layanan yang baik merupakan suatu bentuk dedikasi untuk memberikan kualitas layanan tertinggi melalui pengiriman yang tepat waktu, responsive, kepercayaan, dan cara professional. Sebagai salah satu vendor untuk pabrik-pabrik sepatu terkemuka di dunia, ketepatan pengiriman barang merupakan hal yang sangat penting karena hal terebut merupakan tolak ukur untuk menghitung kinerja pengiriman.

Dalam beberapa bulan belakangan ini delivery performance PT. Pelangi Elasindo terhadap Produk R754046 Moulded Cardboard Shape mengalami penurunan kinerja pengiriman yaitu pada bulan Januari dengan rincian minggu pertama dan kedua yaitu $97 \%$, minggu ketiga yaitu $92 \%$ minggu ke empat yaitu 91\% dan minggu kelima yaitu 90\% sehingga rata-rata delivery performance bulan Januari sebeasar 93\%. Nilai ini dibawah stan- 
dar minimal delivery performance Perusahaan yang sebesar $95 \%$. Penurunan tersebut disebabkan adanya keterlambatan pengiriman barang ke custumer. Untuk itu Penelitian ini bertujuan menganalisa faktor-faktor keterlambatan pengiriman barang ke custumer, sehingga dapat memperbaiki dan meningkatkan kinerja pengiriman.

Berdasarkan observasi yang telah dilakukan di PT Pelangi Elasindo salah satu penyebab adanya keterlambatan adanya ketidakpastian permintaan dan leadtime produksi. Sehinga guna memperbaiki kinerja pengriman ke custumer di perlukan persedian pengamanan (safety stock) untuk barang jadi R754046 size 2. Persediaan pengamanan adalah suatu persediaan tambahan yang memungkinkan permintaan yang tidak seragam menjadi sebuah cadangan (Heizer dan Render, 2011:76).

Berdasarkan pada hasil observasi yang telah dilakukan di PT Pelangi Elasindo terhadap keterlambatan pengiriman produk R754046 Moulded Cardboard Shape, penulis melakukan penelitian dengan tema perbaikan kenerja pengiriman produk R754046 di PT Pelangi Elasindo dengan pendekatan safety stock.

\section{METODOLOGI PENELITIAN \\ 1. Jenis penelitian}

Metode penelitian yang digunakan adalah metode penelitian kuantitatif dengan analisis matematis. Penelitian ini dilakukan dengan pengumpulan data permintaan dari customer dan menganalisa secara matematis.

\section{Sumber dan Metode Pengambilan Data}

Jenis dan sumber data penelitian ini adalah:

(a). Data Primer adalah data hasil observasi, wawancara dan dokumentasi.

(b). Data sekunder bersumber dari buku literature, jurnal ilmiah, dan sumber dari website.

dengan:

Metode pengambilan data dilakukan

\section{(a). Metode Observasi}

Proses pengamatan dan pencatatan secara sistematis mengenai gejala-gejala yang diteliti. Observasi ini menjadi salah satu dari teknik pengumpulan data apabila sesuai dengan tujuan penelitian, yang direncanakan dan dicatat secara sistematis.

\section{(b). Studi pustaka}

Pada tahap ini dilakukan studi pustaka berupa buku, jurnal, Laporan KP yang sudah ada, serta dokumen sebagai landasan serta penunjang data dalam laporan.

(c). Metode Wawancara (Interview)

Wawancara dilakakuan dengan melakukan Tanya jawab secara langsung kepada karyawan PT Pelangi Elasindo yaitu manager produksi divisi Moulded Pulp, admin produksi, staf pengiriman da beberapa bagian yang berhubungan dengan penujang informasi laporan.

\section{Rumusan Masalah}

Perumusan masalah yang akan dibahas dalam penelitian ini adalah:

(a). Faktor apa saja yang menyebabkan terjadinya penurunan kinerja pengiriman produk R754046.

(b). Bagaimana memperbaiki kinerja pengiriman produk R754046 di PT Pelangi Elasindo.

\section{Tujuan Penelitian}

Berdasarkan perumusan masalah, maka tujuan penelitian ini adalah sebagai berikut:

(a). Mengetahui faktor-faktor penyebab penurunan kinerja produk R754046,

(b). Memperbaiki kinerja pengiriman produk R754046 di PT Pelangi Elasindo.

\section{LANDASAN TEORI}

1. Delivery Performance (Kinerja Pengiriman)

Kinerja pengiriman adalah pengukuran KPI standar yang banyak digunakan dalam rantai pasokan untuk mengukur pemenuhan permintaan pelanggan hingga tanggal yang diinginkan. (Diterjemahkan dari https://en.wikipedia.org/wiki/DeliveryPerform ance). Tautan dalam rantai pasokan yang berhubungan langsung dengan pelanggan adalah pengiriman barang atau jasa dan oleh karena itu disebut "penggerak kepuasan pelanggan". Pengiriman adalah layanan, dimensi terpenting dari layanan adalah ketergantungan. Pengiriman beroperasi dalam lingkungan yang dinamis dan selalu berubah. Salah satu cara untuk mengatasi masalah ini adalah memiliki pandangan sistem total dengan tujuan memahami dan mengukur kinerja sistem secara keseluruhan, serta dalam kaitannya dengan berbagai aktor. 
Kinerja pengiriman dapat diukur sebagai persentase dari pesanan pelanggan yang dikirimkan "tepat waktu dan penuh" (OTIF). Tepat waktu adalah tanggal ketika pelanggan ingin memiliki barang (tanggal yang diminta) atau ketika pelanggan dan pemasok telah menyetujui tanggal (tanggal komitmen). Secara penuh adalah ketika pemasok mengirimkan semua barang yang telah dipesan pelanggan. Alasan mengapa ada dua definisi berbeda pada tanggal pengiriman harus dilakukan adalah bahwa pemasok mungkin tidak dapat memberikan ketika pelanggan ingin memiliki pesanan.

Untuk menghitung OTIF ke tanggal komitmen pelanggan, Anda menghitung dengan mengambil jumlah total pesanan yang dikirimkan tepat waktu dan secara penuh ke tanggal komitmen pelanggan dibagi dengan jumlah total pesanan pelanggan.

\section{Persediaan}

Persediaan (Inventory) adalah suatu istilah umum yang menunjukan segala sesuatu atau sumber daya-sumber daya organisasi yang disimpan dalam antisipasinya terhadap pemenuhan permintaan, (Handoko, 1994). Menurut Prawirosentono (2005), persediaan adalah aset cair yang dimiliki perusahaan dan tersimpan dalam bentuk barang menatah (raw material), bahan setengah jadi (work in process), dan produk akhir (finished goods). Herjanto (1999) mendefinisikan persediaan sebagai bahan atau barang yang disimpan kemudian akan digunakan untuk memenuhi tujuan tertentu, misalnya produksi atau perakitan, untuk suku cadang dari suati peralatan atau mesin. Nasution (2008) mendefinisikan persediaan sebagai sumber daya tersimpan (idle recources) yang dipersiapkan untuk proses lebih berikutnya. Yang dimaksud dengan proses lanjut tersebut adalah berupa kegiatan produksi pada sistem manufaktur, kegiatan pemasaran pada sistem distribusi ataupun kegiatan konsumsi pada sistem rumah tangga.

Dalam sistem manufaktur, berdasarkan jenisnya terdapat 4 macam persediaan secara umum yaitu sebagai berikut (Nasution dan Prasetyawan, 2008):

a) Bahan baku (raw materials) adalah barang-barang yang dibeli dari pemasok (supplier) dan akan digunakan atau diolah menjadi produk jadi yang akan dihasilkan oleh perusahaan; b) Bahan setengah jadi (work in process) adalah bahan baku yang sudah diolah atau dirakit menjadi komponen namun masih membutuhkan langkah-langkah lanjutan agar menjadi produk jadi;

c) Barang jadi (finished goods) adalah barang jadi yang telah selesai diproses, siap untuk disimpan di gudang barang jadi, dijual, atau didistribusikan ke lokasilokasi pemasaran; dan

d) Bahan-bahan pembantu (supplies) adalah barang-barang yang dibutuhkan untuk menunjang produksi, namun tidak akan menjadi bagian pada produk akhir yang dihasilkan perusahaan.

Manfaat utama persediaan yaitu untuk memastikan terpenuhinya permintaan produk yang sesuai dengan permintaan pelanggan sehingga kinerja (performance) sistem menjadi optimal. Adanya persediaan dalam sistem, apakah itu sistem manufaktur maupun non manufaktur disebabkan oleh 3 kondisi, yaitu (Nasution dan Prasetyawan, 2008):

a) Mekanisme pemenuhan atas permintaan (transaction motive);

b) Adanya keinginan untuk meredam ketidakpastian (precautionary motive). Ketidakpastian yang dimaksud adalah sebagai berikut:

a. Adanya permintaan yang bervariasi dan tidak pasti dalam jumlah maupun waktu kedatangan,

b. Waktu pembuatan yang cenderung tidak konstan antara satu produk dengan produk lainnya,

c. Waktu ancang-ancang (lead time) yang cenderung tidak pasti karena berbagai faktor yang tidak dapat dikendalikan sepenuhnya,

d. Ketidakpastian ini akan diantisipasi oleh jenis persediaan yang disebut persediaan pengaman (safety stock).

c) Keinginan melakukan spekulasi (speculative motive) yang bertujuan mendapatkan keuntungan besar dari kenaikan harga barang dimasa mendatang.

\section{Persedian Pengamanan}

Pengertian persediaan pengaman (safety stock) adalah persediaan yang harus selalu ada untuk mengantisipasi kemungkinan terjadinya kekurangan bahan (Stock Out) (Rangkuty, 2004). Menurut Sofjan Assauri (2004), perse- 
diaan pengaman yaitu persediaan tambahan yang diadakan untuk melindungi atau menjaga kemungkinan terjadi kekurangan bahan (Stock Out), sedangkan pengertian menurut Zulfikarijah (2005), Persediaan pengaman adalah persediaan yang digunakan agar tidak terjadi stock out (kehabisan stock).

Untuk memesan suatu barang sampai barang tersebut diterima memerlukan jangka waktu yang berbeda-beda. Jangka waktu antara saat memesan sampai saat barang diterima didefinisikan sebagai waktu tenggang (lead time). Waktu tenggang sangat dipengaruhi oleh ketersediaan dari barang itu sendiri dan jarak lokasi antara pembeli dan pemasok berada. Adanya waktu tenggang ini mengharuskan adanya persediaan dalam jumlah tertentu sebagai cadangkan untuk memenuhi kebutuhan selama waktu tenggang yang disebut sebagai persediaan pengaman atau safety stock (Herjanto, 2009).

Persediaan pengaman berfungsi untuk melindungi atau menjaga kemungkinan terjadiya kekurangan barang, misalnya karena penggunaan barang yang lebih besar dari perkiraan semula atau keterlambatan dalam penerimaan barang yang dipesan. Istilah lain dari Persediaan pengaman adalah persediaan penyangga atau buffer stock.

Tujuan safety stock adalah untuk mengurangi kemungkinan terjadinya stock out . Keuntungan adanya safety stock adalah pada saat jumlah permintaan mengalami lonjakan, maka persediaan pengaman dapat digunakan untuk menutup permintaan tersebut.

Beberapa faktor yang mempengaruhi perusahaan untuk melakukan safety stock adalah sebagai berikut (Zulfikarijah, 2005):

a) Biaya atau kerugian yang disebabkan oleh stock out tinggi. Apabila bahan yang digunakan untuk proses produksi tidak tersedia, maka aktivitas perusahaan akan terhenti yang menyebakan terjadinya idle tenaga kerja dan fasilitas pabrik yang pada akhirnya perusahaan akan kehilangan penjualannya;

b) Variasi atau ketidakpastian permintaan yang meningkat. Persediaan pengaman akan diperlukan saat terjadi peningkatan permintaan melebihi yang sudah direncanakan;

c) Resiko stock out meningkat. Keterbatasan jumlah persediaan yang ada dipasar dan kesulitan yang dihadapi perusahaan men- dapatkan persediaan akan berdampak pada sulitnya terpenuhi persediaan yang ada diperusahaan, kesulitan ini akan menyebabkan perusahaan mengalami stock out; dan

d) Biaya penyimpanan safety stock yang murah. Apabila perusahaan memiliki gudang yang memadai dan memungkinkan, maka biaya penyimpanan tidaklah terlalu besar hal ini dimaksudkan untuk mengantisipasi terjadinya stock out.

Dalam menentukan safety stock terdapat metode yang dapat digunakan oleh perusahaan. Berikut ini adalah beberapa metode tersebut (Nasution, 2008):

a) Intuisi

Penentuan safety stock berdasarkan pengalaman sebelumnya.

b) Service level tertentu

Metode ini mengukur seberapa efektif perusahaan mensuplai permintaan barang dari stocknya. Diperlukan metode statistik untuk pemenuhan permintaan, untuk itu diperlukan data histori mengenai variasi lead time dan variasi permintaan dalam menentukan safety stock.

c) Permintaan dengan distribusi empiris

Penentuan persediaan didasarkan pada kondisi riil yang dihadapi oleh perusahaan dengan pendekatan pengalaman empiris.

d) Permintaan distribusi normal

Meskipun jumlah permintaan pelanggan dalam kondisi realnya adalah bervariasi tetapi variasi permintaan tersebut dapat diasumsikan terdistribusi secara normal dengan tingkat kepercayaan tertentu.

e) Lead time tidak past

Ketidakpastian jumlah permintaan pada periode tertentu akan berakibat variasi lead time untuk setiap siklus pemesanan. Hal tersebut yang menyebabkan perusahaan akan menyediakan safety stock atau buffer stock selama lead time.

f) Biaya stock out

Peningkatan biaya penyimpanan akan meningkat service level, sehingga semua usaha yang digunakan untuk menutup semua level yang memungkinkan pada saat terjadi lead time permintaan merupakan tujuan yang sangat sulit dicapai. Untuk semua produk, permintaan maksimum akan lebih murah dibandingkan dengan terjadinya stock out. 
Untuk memesan suatu barang sampai barang itu datang, diperlukan jangka waktu yang bervariasi dari beberapa jam sampai beberapa bulan. Perbedaan waktu antara saat memesan sampai saat barang datang dikenal dengan istilah waktu tenggang (leadtime). Waktu tenggang sangat dipengaruhi oleh ketersediaan dari barang itu sendiri dan jarak lokasi antara pembeli dan pemasok berada. Maka dari itu safety stock sangat diperlukan.

Penghitungan persediaan pengaman (safety stock) menurut ahli atau pakar yakni Heizer dan Render (2011:322) yang dapat dijelaskan dan diuraikan sebagai berikut:

\section{Safety Stock $=\mathrm{z} \times \alpha$}

\section{Dimana:}

$\mathrm{z} \quad=$ standar normal deviasi (standar level).

$\alpha=$ standar deviasi dari tingkat kebutuhan yang dirumuskan:

$$
\alpha=\sqrt{\sum \frac{(X-\bar{X})^{2}}{n}}
$$

Dimana:

$$
\begin{array}{ll}
\mathrm{x} & =\text { variable bebas } \\
\mathrm{n} & =\text { jumlah sampel }
\end{array}
$$

Nilai safety stock dihitung berdasarkan standar deviasi permintaan per periode dan standar deviasi lead time. Jika permintaan perperiode dan lead time sama-sama konstan maka tidak perlu safety stock, karena permintaan selama lead time memiliki standar deviasi 0 . Jika permintaan per periode dan lead time tidak menentu maka standar deviasi permintaan selama lead time ( $\mathrm{Sdl}$ ) dapat dihitung sbb:

$$
S d l=\sqrt{\left(d^{2} x S l^{2}\right)+\left(l x S d^{2}\right)}
$$

Dimana:

Sdl = Standar deviasi permintaan selama lead time

$\mathrm{d} \quad=$ rata-rata permintaan per periode

$1=$ rata-rata lead time

S1 $=$ standar deviasi lead time

$\mathrm{Sd}=$ standar deviasi permintaan

\section{ANALISA DAN PEMBAHASAN}

1. Data Hasil Pengamatan

a) Data Delivery Peformance

Data delivery performance yang digunakan dalam penelitian ini adalah delivery performance periode Januari-Maret 2019 pengi- riman PT Pelangi elasindo kepada PT X teradap produk R754046 Moulded Cardboardshape size 2)

Data kinerja pengiriman PT Pelangi terhadap custumer $\mathrm{X}$ periode Januari-Maret 2019 dapat dilihat pada tabel 1 tabel 2 dan tabel 3.

Tabel 1. Delivery Performance

PT Pelangi Elasindo Bulan Januari 2019

\begin{tabular}{|l|c|c|c|c|c|}
\hline Week & $1-2$ & 3 & 4 & 5 & $\begin{array}{c}\text { Rata- } \\
\text { rata }\end{array}$ \\
\hline $\begin{array}{l}\text { Delivery } \\
\text { Performance }\end{array}$ & $97 \%$ & $92 \%$ & $91 \%$ & $90 \%$ & $93 \%$ \\
\hline
\end{tabular}

Tabel 2. Delivery Performance

PT Pelangi Elasindo Bulan Februari 2019

\begin{tabular}{|l|c|c|c|c|c|}
\hline Week & 6 & 7 & 8 & 9 & $\begin{array}{c}\text { Rata- } \\
\text { rata }\end{array}$ \\
\hline $\begin{array}{l}\text { Delivery } \\
\text { Performance }\end{array}$ & $100 \%$ & $83 \%$ & $89 \%$ & $\begin{array}{c}100 \\
\%\end{array}$ & $93 \%$ \\
\hline
\end{tabular}

Tabel 3. Delivery Performance

PT Pelangi Elasindo Bulan Maret 2019

\begin{tabular}{|l|c|c|c|c|c|}
\hline Week & 10 & 11 & 12 & 13 & $\begin{array}{c}\text { Rata- } \\
\text { rata }\end{array}$ \\
\hline $\begin{array}{l}\text { Delivery } \\
\text { Performance }\end{array}$ & $100 \%$ & $93 \%$ & $92 \%$ & $95 \%$ & $95 \%$ \\
\hline
\end{tabular}

b) Data permintaan

Data permintaan PT X terhadap produk R754046000 periode Januari - Maret 2019 dapat dilihat pada tabel 4.4

Tabel 4. Data Kebutuhan Produk R754046* Periode Jan-Mar 2019

\begin{tabular}{|r|r|r|c|}
\hline No & Week & $\begin{array}{l}\text { Permintaan } \\
(\mathrm{x})(\mathrm{PRS})\end{array}$ & $\begin{array}{c}\text { Leadtime } \\
\text { (Hari) }\end{array}$ \\
\hline 1 & 1 & 7,000 & 4 \\
\hline 2 & 2 & 16,000 & 3 \\
\hline 3 & 3 & 23,000 & 4 \\
\hline 4 & 4 & 23,000 & 3 \\
\hline 5 & 5 & 20,000 & 4 \\
\hline 6 & 6 & 15,000 & 4 \\
\hline 7 & 7 & 26,000 & 2 \\
\hline 8 & 8 & 20,000 & 3 \\
\hline 9 & 9 & 11,500 & 3 \\
\hline 10 & 10 & 13,000 & 4 \\
\hline 11 & 11 & 20,000 & 2 \\
\hline 12 & 12 & 26,000 & 4 \\
\hline 13 & 13 & 17,000 & 5 \\
\hline \multicolumn{2}{|c|}{ TOTAL } & 237,500 & 45 \\
\hline
\end{tabular}


Berdasarkan tabel 4. maka simpangan baku (standar deviasi) permintaan yaitu:

$$
\begin{aligned}
\boldsymbol{S} & =\sqrt{\frac{\boldsymbol{\Sigma} \boldsymbol{f}_{i}\left(\boldsymbol{x}_{i}-\overline{\boldsymbol{x}}\right)^{2}}{\boldsymbol{n}-\mathbf{1}}} \\
S & =\sqrt{\frac{391,307,692.31}{13-1}} \\
& =\sqrt{32,608,974.36}=5,710
\end{aligned}
$$

dan simpangan baku (standar deviasi) leadtime yaitu:

$$
\begin{aligned}
& S=\sqrt{\frac{\Sigma f_{i}\left(x_{i}-\bar{x}\right)^{2}}{n-1}} \\
& S=\sqrt{\frac{9.231}{13-1}} \\
& =\sqrt{0.769}=0.877
\end{aligned}
$$

\section{Analisis Data}

Berdasarkan table 1. hingga table 3 . terlihat adanya fluktuasi delivery performance atau kinerja pengiriman, dengan nilai terendah pada bulan januari dan februari yaitu sebesar 93\%, hal tersebut jauh dari standar PT Pelangi Elasindo yaitu minimal $95 \%$.

Beberapa faktor yang mempengaruhi penurunan kinerja pengiriman PT Pelangi Elasindo, yaitu:

a) Kerusakan Mesin

Salah satu mesin yang memiliki dampak paling tinggi terhadap kerusakan adalah mesin forming. Karena proses forming merupakan proses awal pembentukan produk yang menentukan jumlah ouput barang.

\section{b) Finishing Cutting Dengan Metode Manual \\ Dalam proses finishing cuting R75404600000 Moulded Pulp Cardboard} Shape masih dilakukan secara manual, sehingga hasil poduksi akan terbatas pada jumlah tenaga kerja. Hal tersebut membuat operator yang ada pada bagian ini harus memiliki kemampuan yang terlatih dalam memotong sesuai pola, dengan cepat dan rapih. Berdasarkan hasil perhitungan yang dilakukan kemampuan operator untuk melakukan finishing cutting yaitu 350 prs per shift (7 jam kerja) atau hasil per jamnya yaitu 50 prs. Adanya keterbatasan tersebut menyebabkan bottle neck pada bagian finishing cutting sebelum masuk ke bagian QC, sehingga hasil finish goods yang siap dikirim akan mengalami pengurangan yang menyebabkan delay pengiriman barang. Hal tersebut berdampak pada menurunnya delivery performance.

c) Ketiakpastian Leadtime dan Quantity Permintaan

Pada tabel 4. Kebutuhan Produk R754046000 size 2, dapat dilihat adanya variasi permintaan dan ketidakpastian leadtime. Adanya ketidakpastiaan jumlah permintaan produk R75404600000 dan leadtime permintaan produk yang beragam mengakibatkan planning produksi tidak bisa diterapkan jangka panjang, sehingga pada saat demand tinggi akan terjadi stock out yang menyebabkan delay pengiriman.

Berdasarkan faktor-faktor yang telah dijelaskan, faktor kerusakan mesin dapat diperbaiki melalui penerapan manjemen perawtan yang baik. Sedangkan proses finishing cuting bisa dilakukan dengan membuat desain proses sehingga memiliki fleksibilitas dalam hal kecepatan proses.

Tulisan ini akan difokuskan pada mengatasi ketidak pastian permintaan dan lead time pemesanan

\section{Perbaikan dengan Pendekatan Safety Stock}

Berdasarkan analisis data, salah satu masalah yang menyebabkan terjadinya penurunan kinerja pengiriman yaitu adanya delay pengiriman yang disebabkan oleh faktor ketidakpastian leadtime permintaan dan variasi permintaan barang. Untuk mengatasi masalah ketidakpastian ini diperlukan adanya persediaan pengaman (safety stock) (Pujawan ER. 2010. "Supply Chain Management"). Persediaan pengaman adalah persediaan tambahan yang diadakan untuk melindungi atau menjaga kemungkinan terjadinya kekurangan bahan (Stock Out) (Rangkuty, 2004).

Nilai safety stock dihitung berdasarkan standar deviasi permintaan per periode dan standar deviasi lead time dengan rumus: 


$$
S d l=\sqrt{\left(d^{2} x S l^{2}\right)+\left(l x S d^{2}\right)}
$$

Dimana:

Sdl $=$ Standar deviasi permintaan selama lead time

$\mathrm{d}=$ rata-rata permintaan per periode

1 = rata-rata lead time

S1 = standar deviasi lead time

$\mathrm{Sd}=$ standar deviasi permintaan

Rumus untuk menghitung standar deviasi permintaan selama lead time (Sdl) dapat ditentukan berdasarkan tingkat konsistensi permintaan dan lead time. Maka, safety stock dapat dihitung dengan rumus sebagai berikut:

$$
S S=Z x S d l
$$

Dimana:

SS = Safety Stock

$\mathrm{Z} \quad$ = Service level, dimana nilainya

berdasarkan tabel service level

(Tabel Z)

Sdl $=$ Standar deviasi permintaan selama lead time

Berdasarkan data permintaan pada Tabel 4. rata-rata permintaan per minggu yaitu 18.269 PRS. Dari hasil perhitungan didapat standar deviasi permintaan sebesar 5.710,43. Dan rata-rata lead time sebesar 3.462 hari. Karena rata-rata permintaan dalam minggu maka rata-rata lead time dalam minggu yaitu 0.577 ( 1 minggu $=6$ hari), dan standar deviasi lead time sebesar 0.877 hari, sehingga harus diubah dalam minggu (mengikuti periode permintaan) menjadi 0,146 (1 minggu $=6$ hari). Sehigga standar deviasi selama lead time yaitu sebagai berikut:

$$
\begin{aligned}
& \boldsymbol{S d l}=\sqrt{\left(\boldsymbol{d}^{2} \boldsymbol{x} \boldsymbol{S l}^{2}\right)+\left(\boldsymbol{l} \boldsymbol{x} \boldsymbol{S} \boldsymbol{d}^{2}\right)} \\
& =\sqrt{\left(18.269^{2} \times 0.146^{2}\right)+\left(0.577 \times 5.710,43^{2}\right)} \\
& S d l=\sqrt{25.929 .749 .81}=5.092,13
\end{aligned}
$$

Berdasarkan hasil perhitungan diperoleh standar deviasi permintaan selama lead time yaitu 5.092,13. Setelah mengetahui standar deviasi permintaan selam lead time perlu ditentukan tingkatan service level perusahaan. Dalam usaha untuk memuaskan custumer PT Pelangi Elasindo menetapkan service level
$95 \%$, atau hanya boleh terjadi stock out sebanyak 5\% dari 100 kali pengiriman. Dengan nilai service level dalam tabel $\mathrm{Z}$ yaitu 1,65. Maka penghitungan safety stock yaitu:

$$
\begin{aligned}
\boldsymbol{S S} & =\boldsymbol{Z} \boldsymbol{x} \boldsymbol{S} \boldsymbol{d} \boldsymbol{l} \\
& =1,65 \times 5.092,13 \\
& =8.402,01 \mathrm{prs} \sim 8.403 \mathrm{prs}
\end{aligned}
$$

Dari hasil perhitungan tersebut, untuk menghindari delay pengiriman karena terjadinya stock out yang diakibatkan adanya ketidakpastiaan lead time dan variasi jumlah permintaan yang menyebabkan adanya penurunan delivery performance pada produk R754046 Moulded Cardboardshape size 2 (CSH 2) maka PT Pelangi Elasindo perlu menyiapkan stock pengamanan sejumlah 8.403 prs per minggu.

\section{KESIMPULAN DAN SARAN \\ 1. Kesimpulan}

Berdasarkan hasil analisa dan pembahasan yang dilakukan terhadap terjadinya penurunan delivery performance (kinerja pengiriman) produk R754046000 Moulded Cardboard Shape size 2 di PT Pelangi Elasindo dapat disimpulkan sebagai berikut:

a. Faktor-faktor yang mempengauhi terjadinya penurunan delivery performance yaitu:

1. Kerusakan pada mesin forming,

2. Finishing cutting dengan metode manual,

3. Ketidakpastiaan leadtime dan permintaan produk

b. Untuk memperbaiki delivery performance produk R754046000 Mouldedpulp Cardboard Shape size 2, yang diakibatkan adanya ketidakpastian leadtime dan jumlah permintaan maka diperlukan safety stock (persediaan pengamanan). Berdasarkan perhitungan data yang telah dilakukan dengan tingkat service level 95\% dan standar deviasi permintaan selama leadtime yaitu 5.092,13 maka safety stock yang perlu disiapkan oleh PT Pelangi Elasindo yaitu sebanyak 8.403 prs per minggu.

\section{Saran}

Dari hasil anilisis dan perhitungan untuk memperbaiki kinerja pengiriman dengan menggunakan safety stock, penulis belum 
mempertimbangkan dan menganalisis biaya persedian yang timbul akibat adanya safety stock, sehingga hasil penelitian ini dapat dilanjutkan oleh penulis yang akan datang. Bagi Perusahaan hasil penelitian ini dapat digunakan sebagai salah satu bahan pertimbangan untuk melakukan perbaikan dalam kinerja pengiriman ataupun manajemen persediaan.

\section{DAFTAR PUSTAKA}

Hedin, Johan, Jonsson, Martin Jonsson, \& L. Johan. (2006). Delivery Performance How to define \& measure delivery performance in a triadic relationship. Master Thesis. School of Management and Economics, Department of Logistics \& Supply Chain Management.

Heizer, Jay dan Barry Render. 2011. Operations Management, Buku 1 edisi ke Sembilan. Jakarta: Salemba Empat.

I Nyoman Pujawan ER. 2010. Supply Chain Management. Surabaya: Penerbit Guna Widya.

Madaniatul M., Nanik. (2017). Titik Pemesanan Kembali (Reorder Point) dalam Pengendalian Persediaan Bahan Baku Tepung Terigu (Studi Kasus Pada Amirah Bakery Tulungagung). Simki-Economic Vol. 01 No. 03.
Murty, Dita H., Jazuli, \& Talitha, Tita. Optimasi Pengendalian Persediaan Bahan Baku di PT Bromindo Mekar Mitra. (http://eprints.dinus.ac.id/17516/1/jurnal _16243.pdf, diakses pada hari Minggu, 19 Mei 2019 Pukul 20.40)

Puspika, Juliana \& Anita, Desi. (2013). Inventory Control dan Perencanaan Persediaan Bahan Baku Produksi Roti Pada Pabrik Roti Bobo Pekanbaru. Jurnal Ekonomi, Volume 21, Nomor 3.

Rangkuti, F. 2004. Manajemen Persediaan Aplikasi di Bidang Bisnis. Jakarta: Erlangga.

Sholihin, Imam N., Mustafid, \& Safitri, Diah. (2014). Analisis Faktor Konfirmatori Strategi Positioning Pasar Modern Indomaret (Studi Kasus Wilayah Tembalang Kota Semarang). Jurnal Gaussian, Volume 3, Nomor 3, Tahun 2014, hlm. $431-440$.

Sulaiman, Fahmi \& Nanda. (2015). Pengendalian Persediaan Bahan Baku dengan Menggunakan Metode EOQ Pada UD. Adi Mabel. Jurnal Teknovasi Volume 02, Nomor 1, 2015, 1-11

https://en.wikipedia.org/wiki/DeliveryPerform ance (Diakses pada hari minggu, 19 Mei Pukul 19.45) 